\title{
Apoptosis Induced by an Anti-Epidermal Growth Factor Receptor Monoclonal Antibody in a Human Colorectal Carcinoma Cell Line and Its Delay by Insulin
}

\author{
Xipu Wu, *‡ Zhen Fan, * Hideo Masui, * Neal Rosen, * and John Mendelsohn** \\ * Department of Medicine, Memorial Sloan-Kettering Cancer Center; and ${ }^{\ddagger}$ Department of Pharmacology, \\ Cornell University Graduate Program in Medical Sciences, New York 10021
}

\begin{abstract}
Both EGF and insulin, or IGF, stimulate the growth of many cell types by activating receptors that contain tyrosine kinase activities. A monoclonal antibody (mAb 225) against the EGF receptor produced in this laboratory has been shown to competitively inhibit EGF binding and block activation of receptor tyrosine kinase. Here we report that a human colorectal carcinoma cell line, DiFi, which expresses high levels of EGF receptors on plasma membranes, can be induced to undergo $G_{1}$ cell cycle arrest and programmed cell death (apoptosis) when cultured with mAb 225 at concentrations that saturate EGF receptors. Addition of IGF1 or high concentrations of insulin can delay apoptosis induced by $m A b 225$, while the $G_{1}$ arrest cannot be reversed by either IGF-1 or insulin. Insulin/IGF-1 cannot activate EGF receptor tyrosine kinase that has been inhibited by mAb 225. Moreover, an mAb against the IGF-1 receptor, which has little direct effect on DiFi cell growth, can block the capacity of insulin/IGF-1 to delay apoptosis induced by mAb 225, suggesting that the insulin/IGF-1-mediated delay of apoptosis is acting through the IGF-1 receptor. In contrast, insulin/IGF-1 cannot delay the apoptosis caused by the DNA damaging agent, cisplatin. The results indicate that EGF receptor activation is required both for cell cycle progression and for prevention of apoptosis in DiFi cells, and that a signal transduction pathway shared by receptors for insulin/IGF-1 and EGF may be involved in regulating apoptosis triggered by blockade of the EGF receptor. ( $J$. Clin. Invest. 1995. 95:1897-1905.) Key words: antibodies, monoclonal - receptors, epidermal growth factor-urogastrone - apoptosis - receptors, insulin-like-growth factor I • colorectal neoplasms
\end{abstract}

\section{Introduction}

EGF is a growth factor that stimulates the proliferation of fibroblasts and most types of epithelial cells. The receptor for EGF is a transmembrane glycoprotein with tyrosine kinase activity

Address correspondence to John Mendelsohn, Laboratory of Receptor Biology, Box 156, Department of Medicine, Memorial Sloan-Kettering Cancer Center, 1275 York Avenue, New York, NY 10021. Phone: 212639-5878; FAX: 212-772-8375.

Received for publication 23 September 1994 and in revised form 13 December 1994.

J. Clin. Invest.

(C) The American Society for Clinical Investigation, Inc. 0021-9738/95/04/1897/09 \$2.00

Volume 95, April 1995, 1897-1905
(1). Many human epithelial tumors have been found to express high numbers of EGF receptors (2-11), and increased receptor levels are associated with a poor clinical prognosis in cancers involving the bladder $(6,9)$, breast $(6,7)$, and lung $(10,11)$. Furthermore, EGF receptor activation has been implicated in autocrine stimulation of cell growth in many experimental studies (12). Therefore, the EGF receptor appears to be an excellent target for antitumor therapy.

We have produced and characterized two mAbs against the human EGF receptor, $225 \operatorname{IgG} 1$ and $528 \operatorname{IgG} 2 a(13,14)$. They bind to the EGF receptor with affinity similar to the natural ligands, EGF and TGF- $\alpha$, compete with ligands for receptor binding, and inhibit ligand-induced activation of receptor tyrosine kinase $(13-16)$. The mAbs have been shown to inhibit proliferation of a variety of cultured tumor cell lines that express EGF receptors and TGF- $\alpha$, including vulva (13-15), breast $(17,18)$, colon $(19,20)$, lung $(21)$, renal $(22)$, and prostate (23) cells. Inhibition of cell growth has been suggested to result from blockade of EGF receptor activation by growth factor either present in the culture medium or produced by the cells in an autocrine fashion (24-26). The mAbs are also able to prevent the growth of EGF receptor-bearing human tumor xenografts in nude mice $(20,24,27-29)$. The initial phase I clinical trials with these $\mathrm{mAbs}$ demonstrated the safety of administering $225 \mathrm{mAb}$ in doses adequate to image tumors and to maintain blood levels $>30 \mathrm{nM}$ (receptor-saturating concentrations) for more than $3 \mathrm{~d}(30)$.

Insulin and IGF-1 are closely related polypeptides with respect to their amino acid sequences, three-dimensional structures, and range of biological activities (31). Their corresponding receptors are similar in their subunit structure and molecular size, and they display cross-reactivity in response to high concentrations of ligand (32-34). Both EGF receptors and IGF-1 receptors belong to the family of tyrosine protein kinases, and they have been shown to phosphorylate some proteins in common (35). It also has been shown that both EGF and IGF-1 can regulate proliferation of the same cells (36).

mAb 225 can successfully prevent the growth of human tumor xenografts in nude mice treated at an early stage, within a week of inoculation, but fail to do so against well-established xenografts of most cell lines tested (27). An exception is the DiFi colorectal adenocarcinoma cell line, which displays the highest sensitivity to mAb 225 of all cell lines studied. Wellestablished xenografts of DiFi cells are completely eradicated after mAb treatment (20). DiFi cells were derived from a patient with a hereditary colorectal carcinoma. They secrete TGF$\alpha$ and express high numbers of membrane-associated EGF receptors $\left(4.8 \times 10^{6}\right.$ receptors $/$ cell $)(37,38)$. The reasons why DiFi cells are extremely sensitive to inhibition by mAb 225 were explored.

Programmed cell death, or apoptosis, is a mode of cell death 
that plays an important role in embryonic development, metamorphosis, organ involution, and tumor growth kinetics. Events associated with this process include activation of a $\mathrm{Ca}^{2+}$-dependent endonuclease (39) and internucleosomal fragmentation of genomic DNA, resulting in formation of a ladder of DNA fragments (40-42). DNA fragmentation is followed by characteristic morphological changes that involve chromatin condensation, nuclear disintegration, and cellular fragmentation into membrane-bound apoptotic bodies $(43,44)$. In the present studies, DiFi cells were examined both biochemically and morphologically after mAb 225 treatment. We found that apoptosis could be induced by mAb 225, which blocks EGF receptor tyrosine kinase. Insulin, or IGF-1, which activates the tyrosine kinase activity of IGF-1 receptors, could delay mAb 225-induced apoptosis. Cell cycle arrest in $G_{1}$ phase also was induced by mAb 225 treatment, but this response to EGF receptor blockade was unaffected by either insulin or IGF-1. The results show that regulation of cell cycle traversal and regulation of apoptosis are separable, and that common pathway (s) activated by both EGF receptors and IGF-1 receptors may be involved in inhibition of apoptosis in these cells.

\section{Methods}

Materials. mAb 225 was produced in this laboratory and has been previously described $(13,14)$. mAbs R1 and $\alpha \mathrm{IR}_{3}$ were generous gifts from Dr. A. L. Harris (Oxford University, Oxford, UK) and Dr. K. Iwata (Oncogene Science, Manhasset, NY), respectively. Antiretinoblastoma (RB) ${ }^{1}$ antibody was purchased from PharMingen (San Diego, CA), and antiphosphotyrosine antibody (PY69) was from ICN Biochemical Inc. (Cleveland, OH). Anti-EGF receptor antibody (RKII) was kindly provided by Dr. J. Schlessinger (New York University Medical Center, New York). EGF and IGF-1 were from Collaborative Research, Inc. (Waltham, MA), and insulin was from Upstate Biotechnology Inc. (Lake Placid, NY). Cisplatin was a gift from the Bristol Myers-Squibb Company (Evansville, IN).

Cell cultures and growth assay. The DiFi human colorectal carcinoma cell line was originally obtained from Dr. B. M. Boman (Creighton University, Omaha, NE). DiFi cells were grown in 1:1 (vol/vol) DME/ Ham's F12 medium supplemented with $10 \%$ FBS at $37^{\circ} \mathrm{C}$ in $5 \% \mathrm{CO}_{2} /$ 95\% air. For each experiment, cultures in $10 \%$ FBS were seeded at low density onto 6-well plates and allowed to attach and to initiate growth in an unsynchronized fashion. The cells were switched to $0.5 \%$ FBS the next day and different agents were added at the concentrations indicated. Cells were trypsinized and counted with a Coulter counter (Coulter Corp., Hialeah, FL) after indicated time intervals.

Analysis of DNA fragmentation. For demonstration of internucleosomal DNA fragmentation, $1 \times 10^{6}$ cells were harvested and washed with PBS solution at $4^{\circ} \mathrm{C}$. Lysis buffer $(200 \mathrm{mM}$ Tris-HCl, pH 8.3, 100 mM EDTA, $1 \%$ SDS, and $0.2 \mathrm{mg} / \mathrm{ml}$ proteinase $\mathrm{K}$ ) was added. After incubation for at least $4 \mathrm{~h}$ at $37^{\circ} \mathrm{C}$, samples were extracted twice with phenol:chloroform:isoamyl alcohol (25:24:1). After digestion with 0.1 $\mathrm{mg} / \mathrm{ml}$ boiled RNase A in $10 \mathrm{mM}$ Tris- $\mathrm{HCl}, \mathrm{pH} 7.5,15 \mathrm{mM} \mathrm{NaCl}$ at $37^{\circ} \mathrm{C}$ for $1 \mathrm{~h}$, DNA was extracted with phenol and precipitated with ethanol. The precipitates were dissolved in TE, pH 8.0 (10 mM Tris$\mathrm{HCl}$ and $1 \mathrm{mM}$ EDTA). $10 \mu \mathrm{g}$ DNA was subjected to electrophoresis on a $1 \%$ agarose gel in TAE buffer ( $40 \mathrm{mM}$ Tris-acetate, $1 \mathrm{mM}$ EDTA). The agarose gel was stained with ethidium bromide, and the resulting DNA fragmentation was visualized by ultraviolet illumination.

Quantitation of DNA fragmentation was determined by the method of Kolber et al. (45) with slight modifications. In brief, cells were

1. Abbreviation used in this paper: $\mathrm{RB}$, retinoblastoma.

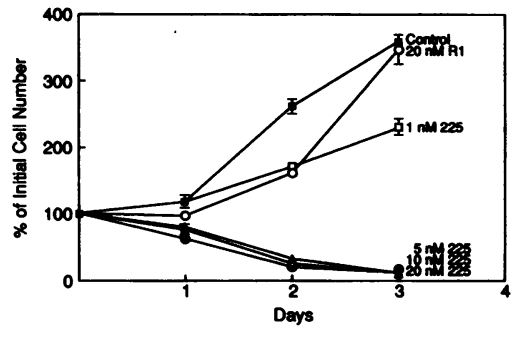

Figure 1. Dose-dependent growth inhibition by mAb 225. DiFi cells were cultured in $0.5 \%$ FBS DME/F12 medium at $37^{\circ} \mathrm{C}$. Different doses of $\mathrm{mAb} 225$ and $\mathrm{R} 1$ were added as indicated. Cells were trypsinized and counted at various time points. Each point represents the mean of triplicate values for each sample \pm SD.

radiolabeled with $20 \mu \mathrm{Ci}\left[{ }^{3} \mathrm{H}\right.$ ] thymidine for $24 \mathrm{~h}$ at $37^{\circ} \mathrm{C}$, washed three times with serum-free medium, and chased in medium with $10 \%$ FBS for $6 \mathrm{~h}$. Labeled cells were exposed to various concentrations of $\mathrm{mAb}$ 225 or $\mathrm{R} 1$ for the indicated time points. Cells were then harvested and washed with PBS at $4^{\circ} \mathrm{C}$ three times, and lysed with $0.4 \mathrm{ml}$ hypotonic lysis buffer containing $0.5 \%$ Triton X-100, $20 \mathrm{mM}$ EDTA, and $5 \mathrm{mM}$ Tris-HCl, $\mathrm{pH} \mathrm{8.0.} \mathrm{After} \mathrm{incubating} \mathrm{at} \mathrm{room} \mathrm{temperature} \mathrm{for} 30 \mathrm{~min}$, samples were centrifugated at $15,000 \mathrm{~g}$ for $30 \mathrm{~min}$. Pellets were washed once with lysis buffer by centrifugation. The radioactivity in the combined supernate (low molecular weight DNA) and in the pellets (intact chromatin DNA) was determined by liquid scintillation counting.

Western blot. After treatment, cells were lysed with SDS sample buffer (2\% SDS-0.5\% 2-mercaptoethanol-10\% glycerol in $62.5 \mathrm{mM}$ Tris-HCl, pH 6.8) and boiled for $5 \mathrm{~min}$. Equal amounts of protein were analyzed by $7 \%$ SDS-polyacrylamide gel electrophoresis. The proteins on the gel were transferred to nitrocellulose and reacted with antiphosphotyrosine PY69, anti-EGF receptor RK II, or anti-RB antibodies. [ ${ }^{125}$ I] protein A (DuPont-New England Nuclear Research Products, Boston, MA) was used as label for autoradiography. When Western blots of EGF receptor tyrosine phosphorylation were performed on lysates and on immunoprecipitates of the receptor, results were comparable in the 170-kD region of the gels because of the great abundance of EGF receptor protein.

Immunoprecipitation. Aliquots of cell lysates containing equal amounts of proteins in $0.5 \% \mathrm{NP}-40$ lysis buffer $(150 \mathrm{mM} \mathrm{NaCl}, 50$ $\mathrm{mM}$ Tris- $\mathrm{HCl}, \mathrm{pH} 7.4,0.5 \% \mathrm{NP}-40,40 \mathrm{mM} \mathrm{NaF}, 1 \mathrm{mM} \mathrm{NaVO}{ }_{4}, 0.3$ $\mathrm{mM}$ PMSF, and $5 \mathrm{mM}$ iodoacetic acid) were precleared with $50 \mu \mathrm{l}$ of $20 \%$ pansorbin cells (Calbiochem Corp., La Jolla, CA) for $1 \mathrm{~h}$ at $4^{\circ} \mathrm{C}$, and then immunoprecipitated with mAb $\alpha \mathbb{I R}_{3}$ plus rabbit anti-mouse antibody (Accurate Chemical \& Scientific Corp., Westbury, NY) and protein A-Sepharose (Pharmacia LKB Biotechnology Inc., Piscataway, $\mathrm{NJ}$ ) as conjugates, for $2 \mathrm{~h}$ at $4^{\circ} \mathrm{C}$.

Cell cycle analysis. Trypsinized cells were washed with serum-free DME/F12 medium twice. Cells were resuspended at $10^{6} \mathrm{cells} / \mathrm{ml}$ in propidium iodide solution $(5 \mathrm{mM} \mathrm{MgCl}, 10 \mathrm{mM}$ Tris- $\mathrm{HCl}, \mathrm{pH} 7.6$, $0.5 \% \mathrm{NP}-40,50 \mu \mathrm{g} / \mathrm{ml}$ propidium iodide, and $100 \mu \mathrm{g} / \mathrm{ml}$ RNase A) and incubated for $30 \mathrm{~min}$ at $37^{\circ} \mathrm{C}$. Cell cycle analysis was then performed on a FACScan ${ }^{\otimes}$ flow cytometer (Becton Dickinson and Co., Cockeysville, MD).

\section{Results}

Induction of cell cycle arrest and apoptosis by mAb 225. Blockade of cell growth by mAb 225 results in cytostatic rather than cytocidal effects in most human tumor cell lines studied (1316). To probe the mechanism of the high sensitivity of DiFi cells to mAb 225 treatment, cell growth kinetics were examined in response to varying doses of mAb 225 (Fig. 1). With $1 \mathrm{nM}$ $\mathrm{mAb} 225$, there was inhibition of growth in comparison with 
Table I. Cell Cycle Distribution of DiFi Cells under Various Conditions

\begin{tabular}{llrr}
\hline & \multicolumn{3}{c}{ Cell cycle distribution (\%) } \\
\cline { 2 - 4 } & $\mathrm{G}_{0} / \mathrm{G}_{1}$ & \multicolumn{1}{c}{$\mathrm{S}$} & \multicolumn{1}{c}{$\mathrm{G}_{2} / \mathrm{M}$} \\
\hline Control & 69.1 & 19.0 & 11.9 \\
$10 \mathrm{nM}$ mAb 225 & 84.6 & 5.9 & 9.6 \\
$10 \mathrm{nM}$ mAb 225 + 10 nM EGF & 52.8 & 29.1 & 18.2 \\
$10 \mathrm{nM} \mathrm{EGF}$ & 56.7 & 29.0 & 14.3 \\
$10 \mathrm{nM}$ mAb 225 + 1 $\mu \mathrm{M}$ insulin & 87.0 & 4.2 & 8.8 \\
$10 \mathrm{nM}$ mAb 225 + 10 nM IGF-1 & 85.8 & 4.6 & 9.6 \\
$1 \mu \mathrm{M}$ insulin & 63.4 & 22.4 & 14.2 \\
\hline
\end{tabular}

Exponentially growing DiFi cells were incubated with various combination of agents for $24 \mathrm{~h}$. Cells were then trypsinized and incubated in propidium iodide solution for $30 \mathrm{~min}$ at $37^{\circ} \mathrm{C}$. The cell cycle distribution was analyzed by flow cytometry.

untreated control cultures. When the concentrations of $\mathrm{mAb}$ 225 were increased to 5,10 , and $20 \mathrm{nM}$, which saturate most of the EGF receptors, cell numbers were reduced to levels lower than the initial cell number before treatment, indicating that cells were killed in response to $\mathrm{mAb}$ treatment. To explore the possible mechanism by which mAb 225 kills cultured DiFi cells, another $\mathrm{mAb}, \mathrm{R} 1$, which binds to EGF receptors but does not compete with ligand binding (46), was assessed in parallel experiments. As shown in Fig. 1, $20 \mathrm{nM}$ mAb R1 had little effect on cell growth. This suggests that blocking of ligand binding is an important factor in cell death resulting from treatment with anti-EGF receptor $\mathrm{mAb}$.

To determine the influence of mAb 225 on cell cycle traversal by DiFi cells, FACS ${ }^{\circledR}$ analysis was performed (Table I). Flow cytometry assays showed that DiFi cells accumulated in $\mathrm{G}_{1}$ phase during exposure to mAb 225 for $24 \mathrm{~h}$. At $24 \mathrm{~h}$, half of the cells originally in $S$ and $G_{2}$ phases had collected in $G_{1}$.

To determine whether DiFi cell death involved apoptosis, we assessed internucleosomal DNA fragmentation and morphological changes after mAb 225 treatment. Analysis of DNA extracts by agarose gel electrophoresis showed a concentrationand time-dependent pattern of an internucleosomal DNA ladder characteristic of apoptosis. At $18 \mathrm{~h}$ we detected no evidence of DNA fragmentation (data not shown). By $24 \mathrm{~h}$, fragmentation was observed with $5 \mathrm{nM} \mathrm{mAb}$ and became very prominent with $20 \mathrm{nM}$ mAb (Fig. $2 \mathrm{~A}$ ). However, control mAb R1 did not cause DNA fragmentation. To quantitatively determine DNA fragmentation, we prelabeled DiFi cell cultures with $\left[\mathrm{H}^{3}\right]$ thymidine and then treated with various concentrations of $\mathrm{mAb}$ 225 or R1 (Fig. $2 B$ ). There was a clear relationship between the amount of fragmented DNA and the concentration of $\mathrm{mAb} 225$.

Fig. 3 demonstrates the typical morphological changes induced by treatment with $\mathrm{mAb} 225$. Compared with the untreated cells (Fig. $3 \mathrm{~A}$ ), DiFi cells treated with $10 \mathrm{nM}$ mAb 225 for $48 \mathrm{~h}$ showed a reduction in cell volume, condensation of nuclear chromatin, and the appearance of nuclear fragmentation (Fig. $3 B$ ) characteristic of apoptosis.

Rescue of mAb 225-induced apoptosis by EGF and by insulin. mAb 225 appears to induce apoptosis by blocking the EGF receptor tyrosine kinase pathway. To confirm this hypothe-

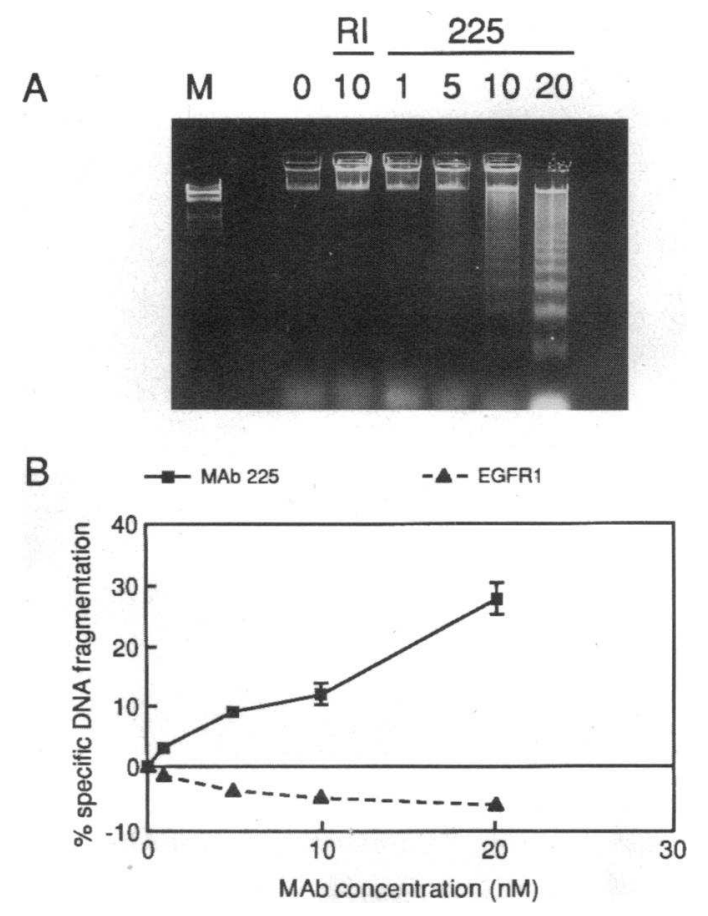

Figure 2. DNA fragmentation induced by mAb 225. (A) DNA assay by gel electrophoresis. DiFi cells in $0.5 \%$ FBS DME/F12 medium were cultured at $37^{\circ} \mathrm{C}$ with different concentrations of $\mathrm{mAb} 225$ (1-20 nM) or $\mathrm{R} 1(10 \mathrm{nM})$ for $24 \mathrm{~h}$. Both floating and attached cells were harvested and lysed with SDS lysis buffer in the presence of proteinase $\mathrm{K}$, followed by incubation for $4 \mathrm{~h}$ at $37^{\circ} \mathrm{C}$. The lysates were then phenol extracted and RNA digestion was performed in RNase $\mathrm{A}$ for $1 \mathrm{~h}$ at $37^{\circ} \mathrm{C}$. DNA was precipitated with ethanol and the concentration was determined. 10 $\mu \mathrm{g}$ DNA was loaded on a $1 \%$ agarose gel with ethidium bromide and electrophoresed. $M$, molecular weight marker. ( $B$ ) Quantitation of DNA fragmentation. Cultures were labeled with $\left[{ }^{3} \mathrm{H}\right]$ thymidine overnight and treated under the same conditions as indicated. Cells were lysed with Triton X-100 lysis buffer. Fragmented DNA was separated from intact nuclear DNA by centrifugation. Both supernate and pellet were counted in scintillation solution. The percentage of fragmented DNA is calculated by supernate counts/supernate + pellet counts. Each point is the average of triplicate values $\pm S D$.

sis, we studied the capacity of EGF to rescue apoptosis mediated by mAb 225 . The $K_{\mathrm{d}}$ for EGF and mAb 225 binding to EGF receptors is identical $(2 \mathrm{nM})$ for all cell lines tested (47), including DiFi cells (data not shown). As shown above, mAb 225 at $10 \mathrm{nM}$ concentrations produced cell death (Fig. $4 \mathrm{~A}$ ). When equimolar concentrations of EGF were added, there was a complete rescue from cell death induced by mAb 225. Paradoxically, with DiFi and with other cell lines that greatly overexpress EGF receptors on plasma membranes, addition of a saturating amount of EGF in the absence of mAb also markedly inhibited cell growth. In comparison with EGF, addition of insulin had little effect on DiFi cell growth in the absence of mAb 225 (Fig. $4 B$ ). Interestingly, insulin could also delay cell death caused by mAb 225. As shown in Fig. $4 B$, insulin plus mAb 225 maintained the initial cell numbers for $2 \mathrm{~d}$, after which cells began to die. Therefore, in contrast to the complete rescue by EGF, insulin only delayed cell death mediated by mAb 225 . Higher concentrations of insulin produced similar results, and IGF-1 produced a response similar to insulin (data not shown). 

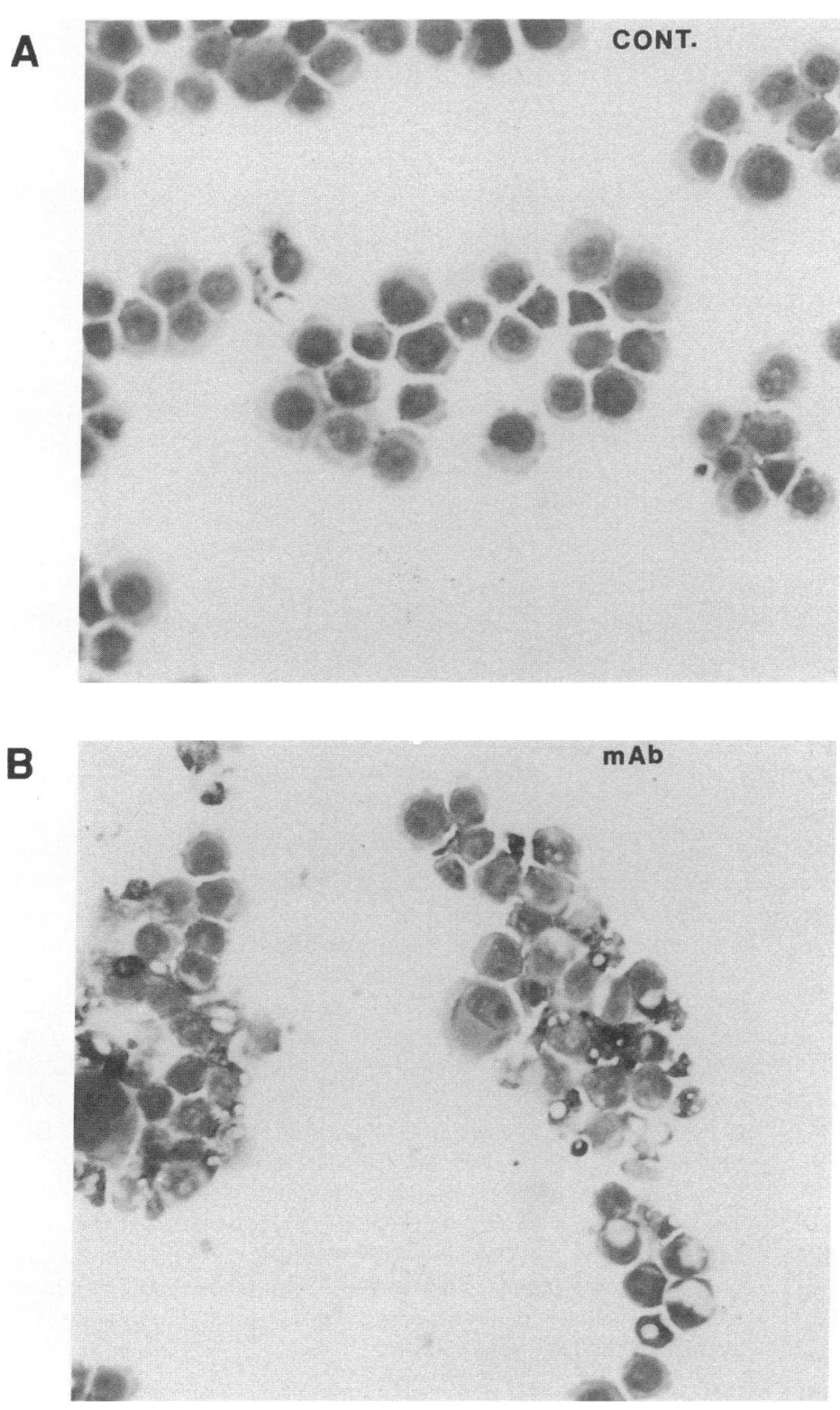

Figure 3. Light microscopic examination of DiFi cells exposed to $\mathrm{mAb} 225$. DiFi cells were either untreated $(A)$ or treated with $10 \mathrm{nM}$ mAb $225(B)$. After a 48-h incubation period, cells were transferred onto microscope slides with a cytospin, fixed, stained with Wright-Giemsa dye, and observed under a light microscope $(\times 400)$.
To confirm that mAb 225-induced apoptosis was delayed by addition of growth factor, the formation of DNA internucleosomal ladders was examined after $1 \mathrm{~d}$ of treatment (Fig. $4 C$ ). $10 \mathrm{nM}$ mAb 225 alone induced a clear DNA ladder, while the addition of either EGF or insulin together with mAb 225 prevented formation of the ladder, suggesting that mAb 225induced apoptosis was rescued by each growth factor. Treatment with EGF alone, in the absence of $\mathrm{mAb}$, resulted in formation of a very faint DNA ladder.

Effect of EGF and insulin/IGF-1 on mAb 225-mediated cell cycle arrest. Addition of EGF in concentrations equivalent to $\mathrm{mAb} 225$ could completely prevent the $G_{1}$ arrest induced by mAb 225 (Table I). However, addition of either insulin or IGF1 with $\mathrm{mAb} 225$ did not influence the mAb 225-mediated cell cycle arrest after $24 \mathrm{~h}$ exposure, at which time the mAb 225 induced apoptosis was effectively delayed by insulin/IGF-1. In the absence of $\mathrm{mAb}$, insulin/IGF-1 alone had no influence on the cell cycle phase distribution, and EGF by itself decreased the fraction of cells in $G_{1}$ phase.

The existence of two RB protein forms that differ in phosphorylation states has been noted previously in most cell types $(48,49)$. The more phosphorylated RB form, designated as $\mathrm{pRB}^{\text {phos }}$, migrates more slowly during SDS gel electrophoresis than the underphosphorylated form, designated as pRB. The $\mathrm{pRB}$ form prevails in mid- $\mathrm{G}_{1}$ cells and is converted to $\mathrm{pRB}^{\text {phos }}$ as cells approach $S$ phase. The $\mathrm{pRB}^{\text {phos }}$ form persists during the rest of the cell cycle, until completion of $M$ phase and entry into $G_{1}$. To further localize the site of cell cycle arrest caused by $\mathrm{mAb} 225$, the phosphorylation state of $\mathrm{RB}$ was visualized by immunoblotting gels of cell lysates with anti-RB mAb (Fig. 5 ). Untreated asynchronously proliferating DiFi cells displayed both phosphorylated and underphosphorylated RB forms with molecular weights of $\sim 110 \mathrm{kD}$. After $24 \mathrm{~h}$ of exposure to mAb 225 , only underphosphorylated RB appeared, indicating that 
A
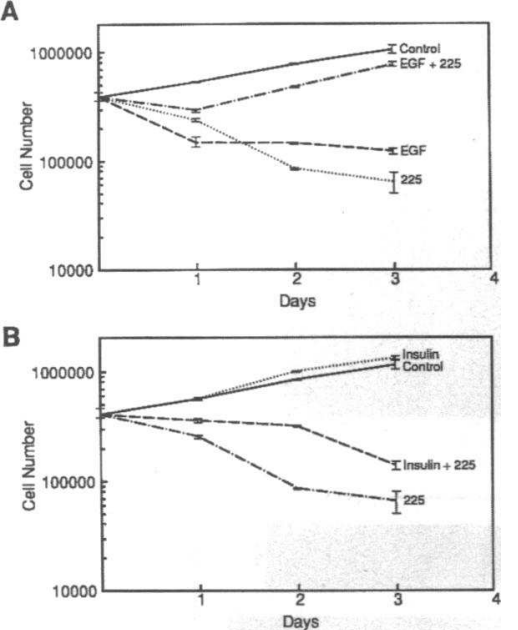

C

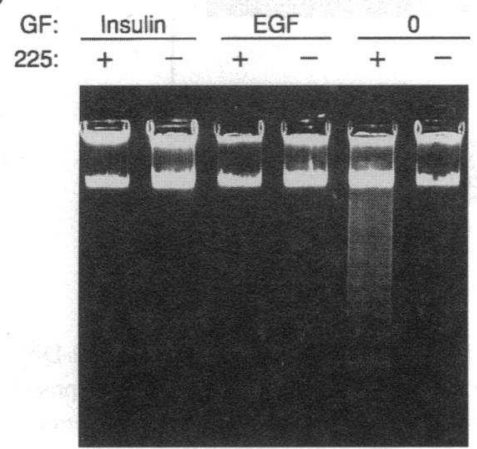

Figure 4. Rescue of $\mathrm{mAb}$ 225-induced cell death by EGF and insulin. $(A, B)$ DiFi cells were treated with various added agents as indicated, for different periods of time. Cell numbers were counted as described in the legend to Fig. 1. ( $C$ ) DiFi cells were treated with various added agents, as indicated, for $24 \mathrm{~h}$. DNA fragments were assayed by agarose gel electrophoresis as described in the legend to Fig. 2. The concentrations of agents used were: EGF, $10 \mathrm{nM}$; insulin, $1 \mu \mathrm{M}$; mAb 225 $10 \mathrm{nM}$. $G F$, growth factor.
A

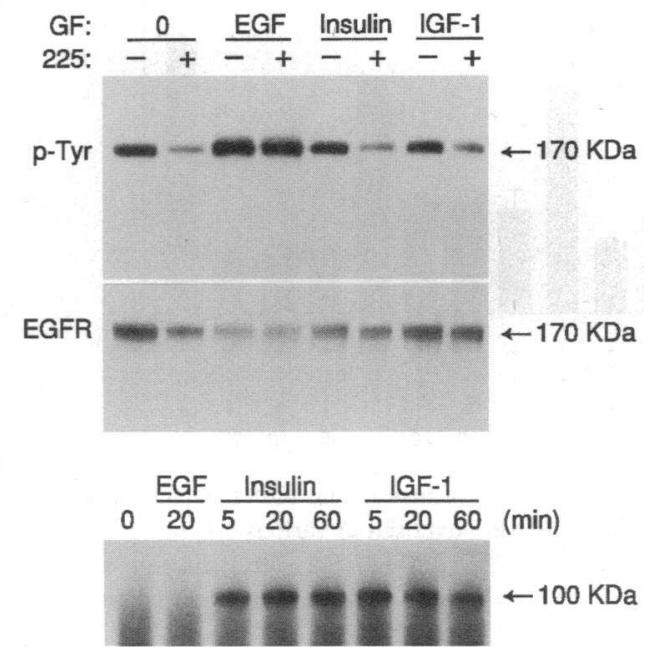

Figure 6. Tyrosine autophosphorylation of EGF and IGF-1 receptor. (A) Immunoblot with antiphosphotyrosine antibody PY69 and with antiEGF receptor antibody RKII. Cells were treated with different agents indicated (10 nM EGF; $1 \mu \mathrm{M}$ insulin; $10 \mathrm{nM} \mathrm{IGF-1;} \mathrm{and} 10 \mathrm{nM} \mathrm{mAb}$ 225 ) for $24 \mathrm{~h}$ and processed for immunoblotting as described in the legend for Fig. 5. (B) Immunoblot of precipitated proteins with antiphosphotyrosine antibody PY69. Cells were treated with growth factors for various times as indicated. Cells were lysed with NP-40 lysis buffer, and equal amounts of proteins were immunoprecipitated with anti-IGF-1 receptor antibody $\alpha \mathrm{IR}_{3}$. The precipitates were analyzed on 7.5\% SDS-PAGE. After transfer to a nitrocellulose membrane, the proteins were blotted with PY69 and autoradiographed.

ined by immunoblot after various treatments for $24 \mathrm{~h}$. The observed basal level of tyrosine phosphorylation resulted from autocrine stimulation by TGF- $\alpha$. mAb 225 caused reduction of EGF receptor autophosphorylation that could be attributed to both blocking of receptor tyrosine kinase activation and downregulation of receptors (Fig. $6 A$ ). EGF stimulated tyrosine phosphorylation, and it greatly downregulated the number of receptors. Insulin/IGF-1 had no effect on EGF receptor level or tyrosine phosphorylation. When EGF was combined with mAb 225 in equimolar amounts, it reversed the block in phosphorylation caused by mAb 225 . In contrast, insulin/IGF-1 failed to reverse the block in phosphorylation caused by $\mathrm{mAb}$ 225. Therefore, it can be concluded that EGF reverses the induction of apoptosis by mAb 225 through competitively binding to and activating EGF receptors, while insulin/IGF-1 delays mAb-mediated apoptosis through a mechanism that does not involve the EGF receptor.

IGF-1 receptors are highly expressed in DiFi cells, as detected by immunoblot (data not shown). To determine the tyrosine phosphorylation status of IGF-1 receptors after stimulation by either EGF or insulin/IGF-1, IGF-1 receptors were first immunoprecipitated with $\alpha \mathrm{IR}_{3} \mathrm{mAb}$ and subsequently immunoblotted with antiphosphotyrosine antibody (Fig. $6 \mathrm{~B}$ ). The results show that both insulin and IGF-1 can activate IGF-1 receptor tyrosine phosphorylation, while EGF has no effect on IGF-1 receptor phosphorylation. It was therefore important to know if IGF-1 receptor activation is a requirement for the delay in $225 \mathrm{mAb}$-mediated apoptosis caused by addition of insulin or IGF-1. 


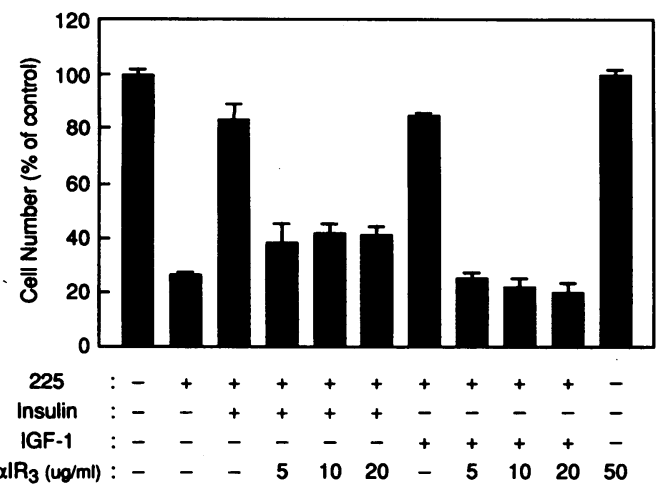

Figure 7. Blockage of effect of insulin and IGF-1 by anti-IGF-1 receptor antibody. DiFi cells were exposed to various conditions as indicated for $48 \mathrm{~h}$. (10 nM mAb 225; $10 \mathrm{nM}$ IGF-1; $1 \mu \mathrm{M}$ insulin; and varying concentrations of antibody $\left.\alpha \mathrm{IR}_{3}\right)$. Cell numbers were counted as described in the legend for Fig. 1.

$\alpha \mathrm{IR}_{3}$ is an mAb against the IGF-1 receptor that can inhibit insulin/IGF-1 binding (50). When $\alpha \mathrm{IR}_{3}$ was used alone, it had little inhibitory effect on DiFi cell growth (Fig. 7). When it was combined with mAb 225 and insulin/IGF-1, the delay of mAb 225-induced cell death by IGF-1 was completely blocked and the delay by insulin was partially blocked, in a dose-dependent manner. Therefore, in the normal situation, DiFi cell survival relies mainly on activation of the EGF receptor signal transduction pathway rather than the IGF-1 pathway. However, if the EGF pathway is inhibited, activation of the IGF-1 pathway (or possibly other pathways) can become critical for DiFi cell survival.

Insulin/IGF-1 delay is specific for mAb 225-mediated apoptosis. A variety of physical and chemical agents can induce apoptosis (51). Though the mechanism of selection of this pathway for cell death is not fully understood, it is clear that cells possess effector mechanisms for self-destruction, which may be activated by several different stimuli. To determine whether insulin delays cell death by acting upon a final common pathway of apoptosis, or whether it specifically delays the apoptosis induced by blocking the EGF receptor signal transduction pathway, the effect of insulin on cell death mediated by cisplatin also was examined (Fig. 8). Cisplatin is an alkylating agent that produces interstrand and intrastrand base crosslinking in DNA, and it is one of the most active drugs against the human epithelial tumors that express high levels of EGF receptors (52). The data in Fig. $8 A$ show that internucleosomal DNA fragmentation and apoptosis can be induced after $24 \mathrm{~h}$ exposure to cisplatin, and that this is concentration dependent. However, in contrast to the delay of mAb 225-mediated cell death by insulin, cell death induced by cisplatin is not prevented by insulin (Fig. $8 \mathrm{~B}$ ).

\section{Discussion}

Culture of DiFi cells with anti-EGF receptor mAb 225 induced cell cycle arrest in $G_{1}$ phase and apoptosis. Tyrosine phosphorylation of EGF receptors stimulated by either endogenous TGF$\alpha$ (Fig. 6) or exogenous EGF (data not shown) was blocked by $\mathrm{mAb} 225$, and this was prevented by coaddition of EGF at
A

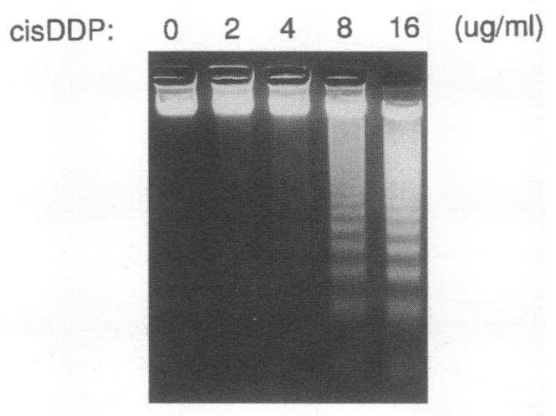

B

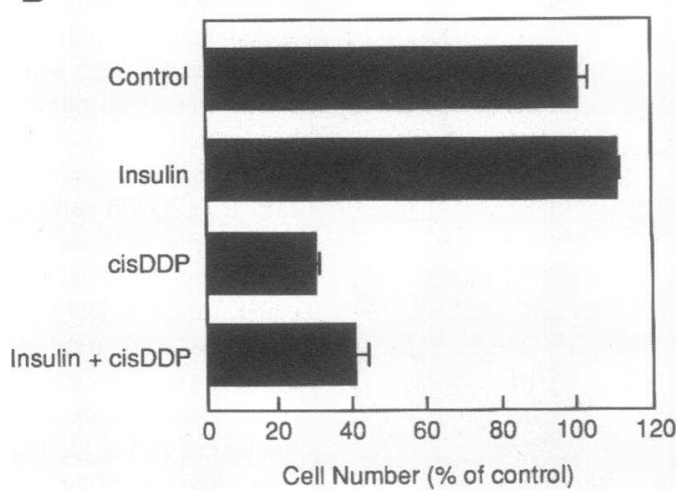

Figure 8. Effect of insulin on cisplatin-induced cell death. (A) DNA fragmentation after treatment with cisplatin. DiFi cells were exposed to different doses of cisplatin as indicated for $24 \mathrm{~h}$. DNA fragmentation was assayed by agarose gel electrophoresis as described in the legend for Fig. 2. (B) DiFi cells were treated with $1 \mu \mathrm{M}$ insulin or $8 \mu \mathrm{g} / \mathrm{ml}$ cisplatin, or both agents, for $24 \mathrm{~h}$. Cells were then counted as described in the legend for Fig. 1.

concentrations equimolar to mAb. mAb 528 against the EGF receptor, which also competitively blocks ligand binding, induced comparable cell cycle arrest and apoptosis in DiFi cells (data not shown), while monoclonal antibody R1 against the EGF receptor, which does not compete with ligand binding, failed to induce arrest and apoptosis. These results strongly suggest that blocking EGF receptor tyrosine kinase activity with mAb 225 leads to cell cycle arrest and apoptosis in DiFi cells.

$G_{1}$ arrest began soon after addition of mAb 225, with $G_{1}$ phase cells rising from $69-85 \%$ at $24 \mathrm{~h}$. Since DiFi cells have a doubling time of $2 \mathrm{~d}$ in culture, we extrapolate that cells in $\mathrm{G}_{1}$ arrest would approach $100 \%$ at $48 \mathrm{~h}$. The location of the arrest within $G_{1}$ phase was defined by the hypophosphorylated state of $\mathrm{Rb}$, signifying a position before the commitment to $\mathrm{S}$ phase progression. Disintegration of DNA into internucleosomal fragments was not detected until $24 \mathrm{~h}$ after addition of $\mathrm{mAb}$. The inhibitory effect of mAb 225 on the cell cycle was reversible. If $\mathrm{mAb}$ was removed from cultures after $24 \mathrm{~h}$, the remaining cells recovered a growth rate that paralleled control cells within a further $24 \mathrm{~h}$ (data not shown). These observations suggest that two events occur in DiFi cells deprived of the EGF receptor-mediated signal transduction pathway: First, cells accumulate in $G_{1}$ phase, an event which is reversible; later, cells undergo programmed cell death.

For most human cell lines that express EGF receptors, the effect of mAb 225 on proliferation is cytostatic. Epidermal car- 
cinoma A431 and breast adenocarcinoma MDA468 are two cell lines that express high levels of EGF receptors and have been extensively studied by ourselves and others. Culture of these tumor cells with saturating concentrations of $\mathrm{mAb} 225$ reduces the rate of proliferation by $50 \%(13-15,18)$, without a $G_{1}$ arrest and without subsequent programmed cell death (data not shown). Addition of mAb 225 to cultures of nonmalignant cell lines, including breast epithelial cells and VACO330 colon adenoma cells, results in arrest of growth with accumulation of cells in $G_{1}$ phase, similar to the response observed in DiFi cells but without subsequent apoptosis $(53,54)$. Thus the DiFi cell line displays both shared and unique responses to EGF receptor blockade. To explain the differences, future studies will compare the responses of these malignant and nonmalignant cell lines by assessing both proximal events in EGF receptor-mediated signal transduction and distal events such as mitogen-activated protein kinase activation and cyclin-dependent kinase activity.

The well-documented capacity of EGF to inhibit proliferation of cells expressing high levels of EGF receptors is demonstrated in Fig. $4 A(55,14)$. We previously explored the dual inhibition produced by anti-EGF receptor $\mathrm{mAb}$ and by EGF in cultures of A431 and MDA468 cells expressing high numbers of receptors $(15,18)$. With these cell lines, as with our current observations on DiFi cells, both blockade of receptors by mAb and stimulation with saturating amounts of ligand produced growth inhibition; furthermore, inhibition by one agent could be reversed by titrating with the other agent. The mechanism of inhibition by EGF when cells express high levels of EGF receptors $\left(5 \times 10^{5}-4 \times 10^{6}\right)$ remains unexplained. The possibility of altered glucose metabolism has been raised (56). Other alternatives include sequestering of SH2-containing docking molecules, or activation of alternative signaling pathways that inhibit growth.

The present experiments contribute a number of observations that indicate that EGF and mAb 225 inhibit DiFi cell growth through unrelated mechanisms: (a) mAb 225 arrested cells in $G_{1}$ phase and prevented cell cycle traversal, whereas EGF did not (Table I); (b) while both mAb and EGF produce cell death, EGF produced only traces of accumulated DNA fragments (Fig. $4 B$ ) and did not cause the morphologic changes characteristic of apoptosis (data not shown); $(c)$ cell death induced by EGF was not delayed by addition of insulin (data not shown). It must be stressed that mAb 225 in either its bivalent or monovalent forms does not activate EGF receptor tyrosine kinase in intact cells $(57,58)$, so that the mechanism of $\mathrm{mAb}$ action is quite different from that of the growth factor. The results of these experiments suggest that EGF receptors may be critical for cell cycle traversal and cell survival through a number of different mechanisms. They also suggest that DiFi cells require an optimal amount of activity in EGF receptormediated signal transduction pathways for cell proliferation and survival, and that too little or too much activity could be harmful to the cells.

The activity of mAb 225 appears to require bivalency, which confers the capacity to induce receptor dimerization $(57,58)$. When experiments were performed with the $225 \mathrm{Fab}^{\prime}$ monovalent fragment, inhibition of DiFi cell growth was markedly reduced (data not shown). This is comparable to our observation of reduced antiproliferative activity of 225 Fab' against a variety of cell lines $(57,58)$.
Insulin, or IGF-1, is able to delay mAb 225-induced apoptosis (Fig. 4). Unlike rescue with EGF, which competes with $\mathrm{mAb} 225$ for receptor binding and activates tyrosine kinase activity, insulin/IGF-1 appears to act through a different mechanism. Insulin/IGF-1 can neither activate tyrosine phosphorylation of EGF receptors (Fig. 6) nor change EGF receptor levels. IGF-1 receptors are expressed in DiFi cells, and their tyrosine kinase activity is activated upon binding of insulin/IGF-1 (Fig. 6). Monoclonal antibody $\alpha \mathbb{I R}_{3}$, which blocks insulin/IGF-1 binding to IGF-1 receptor, can completely inhibit the delay of apoptosis by IGF-1 (Fig. 7), which suggests that IGF-1 delays $\mathrm{mAb} 225$-mediated apoptosis by binding to and activating IGF1 receptors. The target protein activated via the IGF-1 receptor may be shared in the signaling pathway activated by the EGF receptor, or it may be unique to the insulin/IGF-1 receptormediated pathway.

It has been observed that EGF may increase IGF-1 production, and an important role of EGF in the proliferation of 3T3 fibroblasts is to activate an autocrine loop via the IGF-1 receptor (59). However, EGF action on DiFi cells does not seem to result from increasing IGF-1 production, since IGF-1 receptor tyrosine phosphorylation is not activated after EGF treatment (Fig. 6), and $\mathrm{mAb} \alpha \mathrm{IR}_{3}$ against the IGF-1 receptor does not induce cell death, unlike mAb 225 (Fig. 7).

Addition of insulin/IGF-1 delayed mAb 225-mediated apoptosis but did not affect $G_{1}$ cell cycle arrest. This suggests that the pathways leading to apoptosis and to $G_{1}$ cell cycle arrest are separable. EGF receptor-mediated signaling pathways that also can be activated by insulin/IGF-1 may prevent apoptosis, while EGF receptor-mediated signaling pathways that cannot be activated by insulin/IGF-1 may regulate movement through $\mathrm{G}_{1}$ phase of the cell cycle. Although the mechanisms that are involved are not clear, the separation of apoptosis and $G_{1}$ cell cycle arrest by the addition of insulin/IGF-1 will help to guide our further studies of regulation of both cell cycle traversal and apoptosis.

Unlike EGF, which can completely rescue mAb 225-induced apoptosis, insulin can only delay apoptosis for $48 \mathrm{~h}$ and fails to do so after $48 \mathrm{~h}$. The reasons why insulin only delays apoptosis instead of accomplishing a complete rescue are unclear. The failure of prolonged rescue is not due to the degradation of insulin in the medium, as cells die even if fresh insulin is added daily (data not shown). One possibility is that longterm treatment with insulin might downregulate IGF-1 receptors and thereby eliminate their corresponding signal required for cell survival. Alternatively, another slower pathway, unrelated to IGF-1 pathways, may be activated after EGF receptor blockade.

\section{Acknowledgments}

This study was supported by grants CA-42060 and CA-37641 from the National Institutes of Health.

\section{References}

1. Carpenter, G. 1987. Receptors for epidermal growth factor and other polypeptide mitogens. Annu. Rev. Biochem. 56:881-914.

2. Ozanne, B., C. S. Richards, F. Hendler, D. Burns, and B. Gusterson. 1986. Over-expression of the EGF receptor is a hallmark of squamous cell carcinomas. J. Pathol. 149:9-14.

3. Sobol, R. E., R. W. Astarita, C. Hofeditz, H. Masui, R. Fairshter, I. Royston, 
and J. Mendelsohn. 1987. Epidermal growth factor receptor expression in human lung carcinomas defined by a monoclonal antibody. J. Natl. Cancer Inst. 79:403407.

4. Veale, D., N. Kerr, G. H. Gibson, and A. L. Harris. 1989. Characterization of epidermal growth factor receptor in primary human non-small cell lung cancer. Cancer Res. 49:1313-1317.

5. Libermann, T. A., N. Razon, A. D. Bartal, Y. Yarden, J. Schlessinger, and H. Soreq. 1984. Expression of epidermal growth factor receptors in human brain tumors. Cancer Res. 44:753-760.

6. Harris, A. L., S. Nicholson, J. R. C. Sainsbury, D. Neal, K. Smith, J. R. Farndon, and C. Wright. 1989. Epidermal growth factor receptors: a marker of early relapse in breast cancer and tumor state progression in bladder cancer; interaction with neu. Cancer Cells (Cold Spring Harbor). 7:353-357.

7. Sainsbury, J. R. C., A. J. Malcolm, D. R. Appleton, J. R. Farndon, and A. L. Harris. 1985. Presence of epidermal growth factor receptors as an indicator of poor prognosis in patients with breast cancer. J. Clin. Pathol. (Lond.). 38:1225-1228.

8. Eisbruch, A., M. Blick, J. S. Lee, P. G. Sacks, and J. Gutterman. 1987. Analysis of the epidermal growth factor receptor gene in fresh human head and neck tumors. Cancer Res. 47:3603-3605.

9. Neal, D. E., M. K. Bennet, R. R. Hall, C. Marsh, P. D. Abel, J. R. C. Sainsbury, and A. L. Harris. 1985. Epidermal growth factor receptors in human bladder cancer: comparison of invasive and superficial tumors. Lancet. 1:366368 .

10. Hendler, F., A. Shum-Siu, L. Nanu, D. Yuan, and B. Ozanne. 1989. Increased EGF receptors and the absence of an alveolar differentiation marker predict a poor survival in lung cancer. Proc. Am. Soc. Clin. Oncol. Annu. Meet. 8:223. (Abstr.)

11. Veale, D., T. Ashcroft, C. Marsh, G. J. Gibson, and A. L. Harris. 1987. Epidermal growth factor receptors in non-small cell lung cancer. Br. J. Cancer. 55:513-516.

12. Mendelsohn, J. 1990. The epidermal growth factor receptor as a target for therapy with antireceptor monoclonal antibodies. Semin. Cancer Biol. 1:339-344.

13. Sato, J. D., T. Kawamoto, A. D. Le, J. Mendelsohn, J. Polikoff, and G. H. Sato. 1983. Biological effect in vitro of monoclonal antibodies to human EGF receptors. Mol. Biol. \& Med. 1:511-529.

14. Kawamoto, T., J. D. Sato, A. Le, J. Polikoff, G. H. Sato, and J. Mendelsohn. 1983. Growth stimulation of A431 cells by EGF: identification of high affinity receptors for epidermal growth factor by an anti-receptor monoclonal antibody. Proc. Natl. Acad. Sci. USA. 80:1337-1341.

15. Kawamoto, T., J. Mendelsohn, A. Le, G. Sato, C. S. Lazar, and G. N. Gill. 1984. Relation of epidermal growth factor receptor concentration to growth of human epidermoid carcinoma A431 cells. J. Biol. Chem. 259:7761-7766.

16. Gill, G. N., T. Kawamoto, C. Cochet, A. Le, J. D. Sato, H. Masui, C. L. MacLeod, and J. Mendelsohn. 1984. Monoclonal anti-epidermal growth factor receptor antibodies which are inhibitors of epidermal growth factor binding and antagonists of epidermal growth factor-stimulated tyrosine protein kinase activity. J. Biol. Chem. 259:7755-7760.

17. Arteaga, C. L., E. Coronado, and C. K. Osborne. 1988. Blockade of the epidermal growth factor receptor inhibits transforming growth factor $\alpha$-induced but not estrogen-induced growth of hormone-dependent human breast cancer. Mol. Endocrinol. 2:1064-1069.

18. Ennis, B. W., E. M. Valverius, M. E. Lippman, F. Bellot, R. Kris, J. Schlessinger, H. Masui, A. Goldenberg, J. Mendelsohn, and R. B. Dickson. 1989. Monoclonal anti-EGF receptor antibodies inhibit the growth of malignant and non-malignant human mammary epithelial cells. Mol. Endocrinol. 3:1830-1838.

9. Karnes, W. E. J., J. H. Walsh, S. V. Wu, R. S. Kim, M. G. Martin, H. C. Wong, J. Mendelsohn, J. G. Park, and F. Cuttitta. 1992. Autonomous proliferation of colon cancer cells that coexpress transforming growth factor alpha and its receptor. Variable effects of receptor-blocking antibody. Gastroenterology. 102:474-485

20. Masui, H., B. Boman, J. Hyman, L. Castro, and J. Mendelsohn. 1991. Treatment with anti-EGF receptor monoclonal antibody causes regression of $\mathrm{DiFi}$ human colorectal carcinoma xenografts. Proc. Am. Assoc. Cancer Res. 32:394. (Abstr.)

21. Reiss, M., E. B. Stash, V. F. Vellucci, and Z. Zhou. 1992. Activation of the autocrine transforming growth factor $\alpha$ pathway in human squamous carcinoma cells. Cancer Res. 51:6254-6262.

22. Atlas, I., J. Mendelsohn, J. Baselga, W. R. Fair, H. Masui, and R. Kumar. 1992. Growth regulation of human renal carcinoma cells: role of transforming growth factor alpha. Cancer Res. 52:3335-3339.

23. Hofer, D. R., E. R. Sherwood, W. D. Bromberg, J. Mendelsohn, C. Lee, and J. M. Kozlowski. 1991. Autonomous growth of androgen-independent human prostatic carcinoma cells: role of transforming growth factor alpha. Cancer Res. 51:2780-2785.

24. Mendelsohn, J., H. Masui, and A. Goldenberg. 1987. Anti-epidermal growth factor receptor monoclonal antibodies may inhibit A431 tumor cell proliferation by blocking on antocrine pathway. Trans. Assoc. Am. Phys. 100:173-178.
25. Mendelsohn, J. 1989. Potential clinical applications of anti-EGF receptor monoclonal antibodies. Cancer Cells (Cold Spring Harbor). 7:359-362.

26. Van de Vijver, M. J., R. Kumar, and J. Mendelsohn. 1991. Ligand-induced activation of A431 cell epidermal growth factor receptors occurs primarily by an autocrine pathway that acts upon receptors on the surface rather than intracellularly. J. Biol. Chem. 266:7503-7508.

27. Masui, H., T. Kawamoto, J. D. Sato, B. Wolf, G. H. Sato, and J. Mendelsohn. 1984. Growth inhibition of human tumor cells in athymic mice by antiepidermal growth factor receptor monoclonal antibodies. Cancer Res. 44:10021007.

28. Masui, H., T. Morayama, and J. Mendelsohn. 1986. Mechanism of antitumor activity of mice for anti-epdiermal growth factor receptor monoclonal antibodies with different isotypes. Cancer Res. 46:5592-5598.

29. Goldenberg, A., H. Masui, C. Divgi, H. Kammrath, K. Pentlow, and J. Mendelsohn. 1989. Imaging of human tumor xenografts with an indium-111 labelled anti-epidermal growth factor receptor monoclonal antibody. J. Natl. Cancer Inst. 81:1616-1625.

30. Divgi, C. R., S. Welt, M. Kris, F. X. Real, S. D. Yeh, R. Gralla, B Merchant, S. Schweighart, M. Unger, and S. M. Larson. 1991. Phase I and imaging trial of indium 111-labeled anti-epidermal growth factor receptor monoclonal antibody 225 in patients with squamous cell lung carcinoma. J. Natl. Cancer Inst. 83:97-104.

31. Rinderknecht, E., and R. E. Humbel. 1978. The amino acid sequence of human insulin-like growth factor and its structural homology with proinsulin. $J$. Biol. Chem. 253:2769-2776.

32. Kasuga, M., E. E. Van Obberghen-Schilling, S. P. Nissley, and M. M. Rechler. 1981. Demonstration of two subtypes of insulin-like growth factor receptors by affinity crosslinking. J. Biol. Chem. 256:5303-5308.

33. Kasuga, M., F. A. Karlsson, and C. R. Kahn. 1982. Insulin stimulates the phosphorylation of the 95,000-dalton subunit of its own receptor. Science (Wash DC). 215:185-186.

34. Jacobs, S., F. C. Kull, H. S. Earp, M. E. Svoboda, J. J. Van Wyk, and P. Cuatrecasas. 1983. Somatomedin-C stimulates the phosphorylation of the $\beta$-subunit of its own receptor. J. Biol. Chem. 258:9581-9584.

35. Girault, J. A., B. Chamak, G. Bertuzzi, H. Tixier, J. K. Wang, D. T. Pang, and P. Greengard. 1992. Protein phosphotyrosine in mouse brain: developmental changes and regulation by epidermal growth factor, type I insulin-like growth factor, and insulin. J. Neurochem. 58:518-528.

36. Chen, M. C., A. T. Lee, and A. H. Soll. 1991. Mitogenic response of canine fundic epithelial cells in short-term culture to transforming growth factor $\alpha$ and insulinlike growth factor 1. J. Clin. Invest. 87:1716-1723.

37. Gross, M. E., M. A. Zorbas, Y. J. Danels, R. Garcia, G. E. Gallick, M Olive, M. G. Brattain, B. M. Boman, and L. C. Yeoman. 1991. Cellular growth response to epidermal growth factor in colon carcinoma cells with an amplified epidermal growth factor receptor derived from a familial adenomatous polyposis patient. Cancer Res. 51:1452-1459.

38. Untawale, S., M. A. Zorbas, C. P. Hodgson, R. J. Coffey, G. E. Gallick S. M. North, D. M. Wildrick, M. Olive, M. Blick, L. C. Yeoman, and B. M Boman. 1993. Transforming growth factor- $\alpha$ production and autoinduction in a colorectal carcinoma cell line ( $\mathrm{DiFi})$ with an amplified epidermal growth factor receptor gene. Cancer Res. 53:1630-1636.

39. Kyprianou, N., H. F. English, and J. T. Isaacs. 1988. Activation of a $\mathrm{Ca}^{2+}$ $\mathrm{Mg}^{2+}$-dependent endonuclease as an early event in castration-induced prostatic cell death. Prostate. 13:103-117.

40. Kyprianou, N., and J. T. Isaacs. 1988. Activation of programmed cell death in the rat ventral prostate after castration. Endocrinology. 122:552-562

41. Kyprianou, N., H. F. English, and J. T. Isaacs. 1990. Programmed cel death during regression of $\mathrm{PC}-82$ human prostate cancer following androgen ablation. Cancer Res. 50:3748-3753.

42. Kyprianou, N., and J. T. Isaacs. 1989. Expression of transforming growth factor- $\beta$ in the rat ventral prostate during castration-induced programmed cell death. Mol. Endocrinol. 3:1515-1522.

43. Kerr, J. F. R., A. H. Wyllie, and A. R. Currie. 1972. Apoptosis: a basic biological phenomenon with wide ranging implications in tissue kinetics. $B r . J$. Cancer. 26:239-257.

44. Wyllie, A. H., J. F. R. Kerr, and A. R. Currie. 1986. Cell death: the significance of apoptosis. Int. Rev. Cytol. 68:251-306.

45. Kolber, M. A., K. O. Broschat, and B. Landa-Gonzalez. 1990. Cytochalasin B induces cellular DNA fragmentation. FASEB (Fed. Am. Soc. Exp. Biol.) J. 4:3021-3027.

46. Waterfield, M. D., E. L. V. Mayers, P. Stroobant, P. L. P. Bennet, S Young, P. N. Goodfellow, G. S. Banting, and B. Ozanne. 1982. A monoclona antibody to the human epidermal growth factor receptor. J. Cell. Biochem. 20:149-161.

47. Mendelsohn, J., H. Masui, H. Sunada, and C. L. MacLeod. 1988. Monoclonal antibodies against the receptor for EGF as potential anticancer agents. In Cellular and Molecular Biology of Tumors and Potential Clinical Applications. J. Minna and W. M. Kuehl, editors. Alan R. Liss, New York. 307-312. 
48. Ludlow, J. W., J. A. Decaprio, C. Huang, W. Lee, E. Paucha, and D. M. Livingston. 1989. SV40 large T antigen binds preferentially to an underphosphorylated member of the retinoblastoma susceptibility gene product family. Cell. 56:57-65.

49. Decaprio, J. A., J. W. Ludlow, D. Lynch, Y. Furukawa, J. Griffin, H. Piwnica-Worms, C. Huang, and D. M. Livingston. 1989. The product of the retinoblastoma susceptibility gene has properties of a cell cycle regulatory element. Cell. 58:1085-1095.

50. Rohlik, Q. T., D. Adams, F. C. Kull, and S. Jacobs. 1987. An antibody to the receptor for insulin-like growth factor I inhibits the growth of MCF-7 cells in tissue culture. Biochem. Biophys. Res. Commun. 149:276-281.

51. Sen, S., and M. D'Incalci. 1992. Apoptosis. Biochemical events and relevance to cancer chemotherapy. FEBS (Fed. Eur. Biochem. Soc.) Lett. 307:122127.

52. Andrews, P. A., and S. B. Howell. 1990. Cellular pharmacology of cisplatin: perspectives on mechanisms of acquired resistance. Cancer Cells (Cold Spring Harbor). 2:35-43.

53. Stampfer, M. R., C. H. Pan, J. Hosoda, J. Bartholomew, J. Mendelsohn, and P. Yaswen. 1993. Blockage of EGF receptor signal transduction causes reversible arrest of normal and immortal human mammary epithelial cells with synchronous re-entry into the cell cycle. Exp. Cell Res. 208:175-188.
54. Markowitz, S. D., K. Molkentin, C. Gerbic, J. Jackson, T. Stellato, and J. K. V. Willson. 1990. Growth stimulation by coexpression of transforming growth factor $\alpha$ and epidermal growth factor-receptor in normal and adenomatous human colon epithelium. J. Clin. Invest. 86:356-362.

55. Gill, G. N., and C. S. Lazar. 1981. Increased phosphotyrosine content and inhibition of proliferation in EGF-treated A431 cells. Nature (Lond.). 293:305307.

56. Kaplan, O., J. W. Jaroszewski, P. J. Faustino, G. Zugmaier, B. W. Ennis, M. Lippman, and J. S. Cohen. 1990. Toxicity and effects of epidermal growth factor on glucose metabolism of MDA-468 human breast cancer cells. J. Biol. Chem. 265:13641-13649.

57. Fan, Z., J. Mendelsohn, H. Masui, and R. Kumar. 1993. Regulation of epidermal growth factor receptor in NIH3T3/HER14 cells by antireceptor monoclonal antibodies. J. Biol. Chem. 268:21073-21079.

58. Fan, Z., Y. Lu, X. Wu, and J. Mendelsohn. 1994. Antibody-induced epidermal growth factor receptor dimerization mediates inhibition of autocrine proliferation of A431 squamous carcinoma cells. J. Biol. Chem. 269:2759527602.

59. Pietrzkowski, Z., C. Sell, R. Lammers, A. Ullrich, and R. Baserga. 1992. Roles of insulinlike growth factor 1 (IGF-1) and the IGF-1 receptor in epidermal growth factor-stimulated growth of 3T3 cells. Mol. Cell. Biol. 12:3883-3889. 